\title{
Morphological and Compositional Analysis of Electrodeposited Indium (III) Sulfide $\left(\operatorname{In}_{2} \mathbf{S}_{3}\right)$ Films
}

\author{
Maqsood Ali Mughal, ${ }^{\text {a,b,z }}$ Robert Engelken, ${ }^{\text {a,b }}$ M. Jason Newell, ${ }^{\text {a,b }}$ Joshua Vangilder, ${ }^{\text {a,b }}$ \\ Shyam Thapa, ${ }^{\text {, }, \mathrm{b}}$ Kayla Wood, ${ }^{\mathrm{a}}$ B. Ross Carroll, ${ }^{\mathrm{c}}$ and J. Bruce Johnson ${ }^{\mathrm{c}}$
}

${ }^{a}$ Optoelectronic Materials Research Laboratory (OMRL), College of Engineering, Arkansas State University-Jonesboro, State University, Arkansas 72467, USA

${ }^{b}$ Environmental Sciences Graduate Program, Arkansas State University-Jonesboro, State University, Arkansas 72467, USA

${ }^{c}$ Department of Chemistry and Physics, Arkansas State University-Jonesboro, State University, Arkansas 72467, USA

Within the last few years, there has been notable progress in understanding the growth mechanisms of semiconductor thin films for photovoltaic (PV) applications. Electrodeposition continues to be a complex deposition technique that can lead to regions of low quality (for example, cracks) in films. Such cracks can form porous zones on the substrate and diminish the heterojunction interface quality of a PV cell. In this paper, electrodeposition of $\mathrm{In}_{2} \mathrm{~S}_{3}$ films was systematically and quantitatively investigated by varying electrodeposition parameters including bath composition, current density, deposition time, and deposition temperature. Their effects upon the morphology, composition, and film growth mechanism were studied with the help of scanning electron microscopy $(S E M)$, energy dispersive X-ray spectroscopy $(E D S)$, and digital imaging analysis (using fracture and buckling analysis software). In addition, the effect of different annealing treatments $\left(200^{\circ} \mathrm{C}, 300^{\circ} \mathrm{C}\right.$, and $400^{\circ} \mathrm{C}$ in air) and coated glass-substrates (Mo, ITO, and FTO) upon the properties of the $\operatorname{In}_{2} \mathrm{~S}_{3}$ films was analyzed. Furthermore, the Taguchi/Design of Experiments (DOE) Method was used to determine the optimal electrodeposition parameters in order to improve the properties.

(C) 2015 The Electrochemical Society. [DOI: 10.1149/2.0431507jes] All rights reserved.

Manuscript received January 30, 2015. Published 00 0, 2015.

Indium (III) sulfide $\left(\mathrm{In}_{2} \mathrm{~S}_{3}\right)$ is a promising semiconductor material (III-VI compound), suited for many technological applications like optoelectronic, ${ }^{1}$ photovoltaic, ${ }^{2}$ and photoelectric devices ${ }^{3}$ due to its stability, large energy bandgap $(\sim 2.3 \mathrm{eV})$, and photoconductive behavior. ${ }^{4} \beta-\mathrm{In}_{2} \mathrm{~S}_{3}$ is an n-type semiconductor material that has been considered as a non-toxic substitute for cadmium containing PV cells. ${ }^{5}$ It has potential to replace cadmium sulfide (CdS) as a buffer layer in copper indium gallium selenide/sulfide (CIGS)-based PV cells due to environmental concerns. ${ }^{6}$ Several reports have been published on synthesis of $\operatorname{In}_{2} \mathrm{~S}_{3}$ films by numerous deposition techniques. These films have exhibited diverse morphologies and structural properties. ${ }^{7-11}$ In $\mathrm{In}_{2} \mathrm{~S}_{3}$ (from atomic layer deposition)-based CIGS PV cells, an efficiency of $16.4 \% \%^{12}$ has been achieved, which is few percent less than the $20.8 \%$ efficiency reported for CdS-based CIGS PV cells with the CdS deposited by chemical bath deposition (CBD). ${ }^{13}$

Electrodeposition is considered an economical and time-saving alternative to vacuum-based techniques for depositing semiconductor thin films onto a substrate with full coverage and high growth yield.$^{14}$ It offers high material utilization efficiency, precise control with proper bath chemistry, and in-situ monitoring. ${ }^{14,15}$ In 2011, electrodeposited $\mathrm{In}_{2} \mathrm{~S}_{3}$-based CIGSe PV cells yielded an energy conversion efficiency of $10.2 \% .{ }^{16}$ However, electrodeposition still remains a complex technique for synthesizing thin films due to several deposition parameters, which can affect the properties of the films. ${ }^{17,18}$ Poor adhesion, nonuniformity, flaking, and cracking ${ }^{19}$ of films are common problems when electrodepositing films onto smooth surfaces, ${ }^{14}$ as nucleation and growth are influenced by various deposition parameters, ${ }^{15}$ surface roughness, and contamination of the surface. ${ }^{17}$

Synthesizing thin films via solution deposition techniques like electrodeposition has the potential for crack formation, pinholes, or blisters resulting from larger deposition rate, ${ }^{20}$ mass transport, ${ }^{21}$ thickness, ${ }^{22}$ etc. In the past, a number of authors have reported issues related to poor adherence, homogeneity, ${ }^{3}$ uniformity, ${ }^{3,18}$ cracks, or pinholes, ${ }^{23-25}$ which occurs regularly in $\operatorname{In}_{2} \mathrm{~S}_{3}$ films synthesized by solution-based deposition techniques. In our previous work, ${ }^{25}$ electrodeposited $\mathrm{In}_{2} \mathrm{~S}_{3}$ films featured cracks and porous zones that can diminish the heterojunction interface quality of a PV cell. The nucleation growth was higher near the edges, and, therefore, we observed that the $\mathrm{In}_{2} \mathrm{~S}_{3}$ films tended to start cracking from the edge of the substrate and eventually flake-off. As the current density/deposition time increased, those cracks tended to propagate into the middle part of the film and, eventually, the film either fell into the solution while pulling-out the substrate, or flaked-off while rinsing with distilled water.

In view of this, an effort has been made to study the morphological and compositional properties of electrodeposited $\operatorname{In}_{2} \mathrm{~S}_{3}$ films, and understand the underlying growth mechanism. Electrodeposition was performed in an ethylene glycol-based electrolytic solution. The morphological and compositional properties of $\operatorname{In}_{2} \mathrm{~S}_{3}$ films were analyzed by varying deposition parameters including bath composition, current density, deposition time, and deposition temperature. In addition, the stoichiometric ratio between sulfur and indium was studied as a function of annealing temperature. The primary goals were to avoid non-uniformity, cracks, and improper stoichiometry. $\operatorname{In}_{2} \mathrm{~S}_{3}$ films were deposited onto three different substrates, namely indium tin oxide (ITO)-, fluorine-doped tin oxide (FTO)-, and molybdenum (Mo)coated glass substrates, to study their effects upon the morphology and composition with respect to the crack density and stoichiometry of the films. The Taguchi Method was used to determine the optimal electrodeposition parameters based upon the data obtained from scanning electron microscopy (SEM), digital imaging analysis (using fracture and buckling analysis software), and energy dispersive X-ray spectroscopy (EDS). The Taguchi Method is an excellent statistical tool to determine the optimal processing parameters and improve the quality of the product, while lowering the ultimate cost through efficient material use and design of experiments (DOE) ${ }^{26}$ Today, it is used with great success in industry (pharmaceutical, agriculture, photovoltaic, etc.) to design experiments for problems with multiple process parameters due to its high practicality and robustness. ${ }^{27}$ With this method we were able to efficiently determine the effect of each electrodeposition parameter upon the morphological and compositional properties of the $\mathrm{In}_{2} \mathrm{~S}_{3}$ films.

\section{Experimental}

Electrodeposition was performed in a three-electrode electrochemical cell (a glass beaker) using a $\mathrm{Ag} / \mathrm{AgCl}$ reference electrode, cathode (coated-glass substrate, $3 \mathrm{~mm}$ thick with target resistivity value of 10 $25 \Omega / \mathrm{sq}$ ), and anode (graphite). Figure 1 shows the schematic diagram of an electrochemical cell.

An electrolytic solution containing $150 \mathrm{ml}$ of ethylene glycol $\left(\mathrm{C}_{2} \mathrm{H}_{6} \mathrm{O}_{2}\right), 0.1 \mathrm{M}$ elemental sulfur $(\mathrm{S}), 0.1 \mathrm{M}$ sodium chloride $(\mathrm{NaCl})$, and $0.05 \mathrm{M}$ indium chloride $\left(\mathrm{InCl}_{3}\right)$ was prepared. $\mathrm{S}$ was dissolved in 


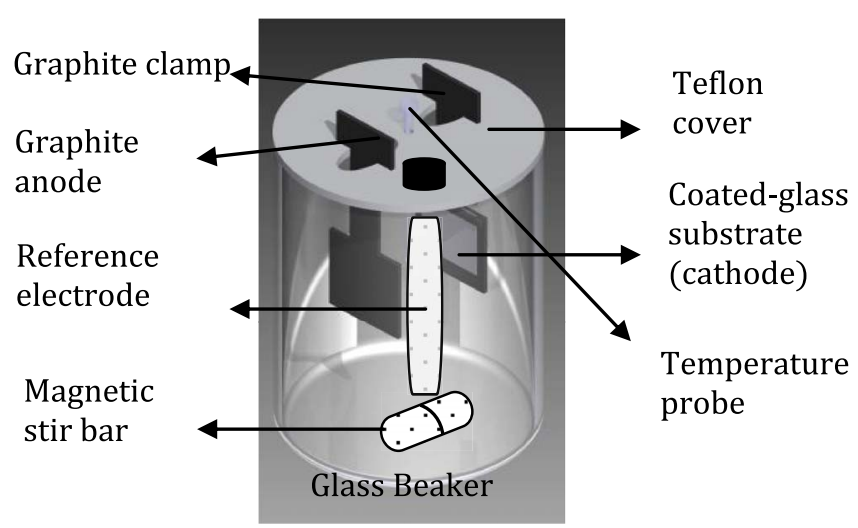

Figure 1. The schematic diagram of an electrochemical cell.

$05\left(\mathrm{C}_{2} \mathrm{H}_{6} \mathrm{O}_{2}\right)$ by heating the solution at $150^{\circ} \mathrm{C}$. After $\mathrm{S}$ melted and fully 106 dissolved, the solution was cooled to $80^{\circ} \mathrm{C}$, and then $\mathrm{InCl}_{3}$ and $\mathrm{NaCl}$ 107 were added. Later, sodium thiosulfate $\left(\mathrm{Na}_{2} \mathrm{~S}_{2} \mathrm{O}_{3} .5 \mathrm{H}_{2} \mathrm{O}\right)$ was added 108 as an additional source of sulfur. The stir rate was kept constant at $109250 \mathrm{rpm}$ while electrodepositing. A digital potentiostat (WaveNow) 110 from Pine Research Instrumentation, Inc. was used in a galvano111 stat mode to perform chronopotentiometry (supplying voltage and 112 current). A digital hotplate from Fisher Scientific (Isotemp 11-400113 49SHP) was used to heat and stir the solution. Prior to deposition, the substrates were thoroughly cleaned in soapy water (using Comet 114 cleaner) with the help of a toothbrush, and then ultrasonically treated 115 (using a Cole Parmer 8890 Ultrasonic cleaner) in distilled water for 45116 minutes at $40^{\circ} \mathrm{C}$ to remove surface contamination. Finally, substrates 117 were rinsed in an acetone solution and dried under flowing air. $\operatorname{In}_{2} \mathrm{~S}_{3} \quad 118$ films were deposited over the $3.75 \mathrm{~cm}^{2}$ (length: $2.5 \mathrm{~cm}$; width: 1.5119 $\mathrm{cm})$ submerged surface area of the glass substrate.

\section{Result Analysis and Discussion}

Statistical analysis. - $\operatorname{In}_{2} \mathrm{~S}_{3}$ films were quantitatively analyzed us- 122 ing Minitab 16 statistical software to perform Taguchi analysis, which 123 helped us to optimize the electrodeposition parameters in order to im- ${ }_{124}$ prove the morphology and composition. Table I lists the deposition 125 parameters and their levels involved in the study. The values of the 126 levels (variables) were varied to measure the effect of individual de- ${ }_{127}$ position parameters upon the output response (mean crack density, \# 128 of cracks $/ \mu \mathrm{m})$, with the least number of experimental runs.

An orthogonal array (design of experiments (DOE)) of $\mathrm{L}_{18}\left(2^{1} \times\right.$ $3^{4}$ ) was selected for conducting experiments, meaning, 2 levels for bath composition, and 3 levels each for the other deposition parameters. For each experiment, 2 samples were generated to minimize the error in the data and achieve balance in the DOE. Therefore, 36 (18 $\times 2$ ) experiments were performed to complete the study as shown in Table II. The effect of each deposition parameter at a given level upon the output response was estimated using analysis of means (ANOM) and analysis of variance (ANOVA).

Table I. Control Deposition Parameters and Levels for the Electrodeposition of $\operatorname{In}_{2} \mathrm{~S}_{3}$ Films.

Deposition Parameters

\begin{tabular}{|c|c|c|c|c|c|}
\hline Levels & $\begin{array}{c}\text { "A" } \\
\text { Bath Composition }\end{array}$ & $\begin{array}{c}\text { "B" } \\
\text { Current Density } \\
\left(\mathrm{mA} / \mathrm{cm}^{2}\right)\end{array}$ & $\begin{array}{c}\text { "C" } \\
\text { Substrate }\end{array}$ & $\begin{array}{c}\text { "D" } \\
\text { Deposition } \\
\text { Time (min) }\end{array}$ & $\begin{array}{c}\text { "E" } \\
\text { Deposition } \\
\text { Temperature }\left({ }^{\circ} \mathrm{C}\right)\end{array}$ \\
\hline 1 & $\begin{array}{c}0.1 \mathrm{M} \mathrm{S}+0.05 \mathrm{M} \mathrm{InCl}_{3} \\
+0.1 \mathrm{M} \mathrm{NaCl}\end{array}$ & 0.75 & Mo & 5 & 140 \\
\hline 2 & $\begin{array}{c}0.1 \mathrm{M} \mathrm{S}+0.1 \mathrm{M} \mathrm{Na}_{2} \mathrm{~S}_{2} \mathrm{O}_{3} .5 \mathrm{H}_{2} \mathrm{O} \\
+0.05 \mathrm{M} \mathrm{InCl}_{3}+0.1 \mathrm{M} \mathrm{NaCl}\end{array}$ & 1.25 & ITO & 10 & 150 \\
\hline 3 & & 1.75 & FTO & 15 & 160 \\
\hline
\end{tabular}

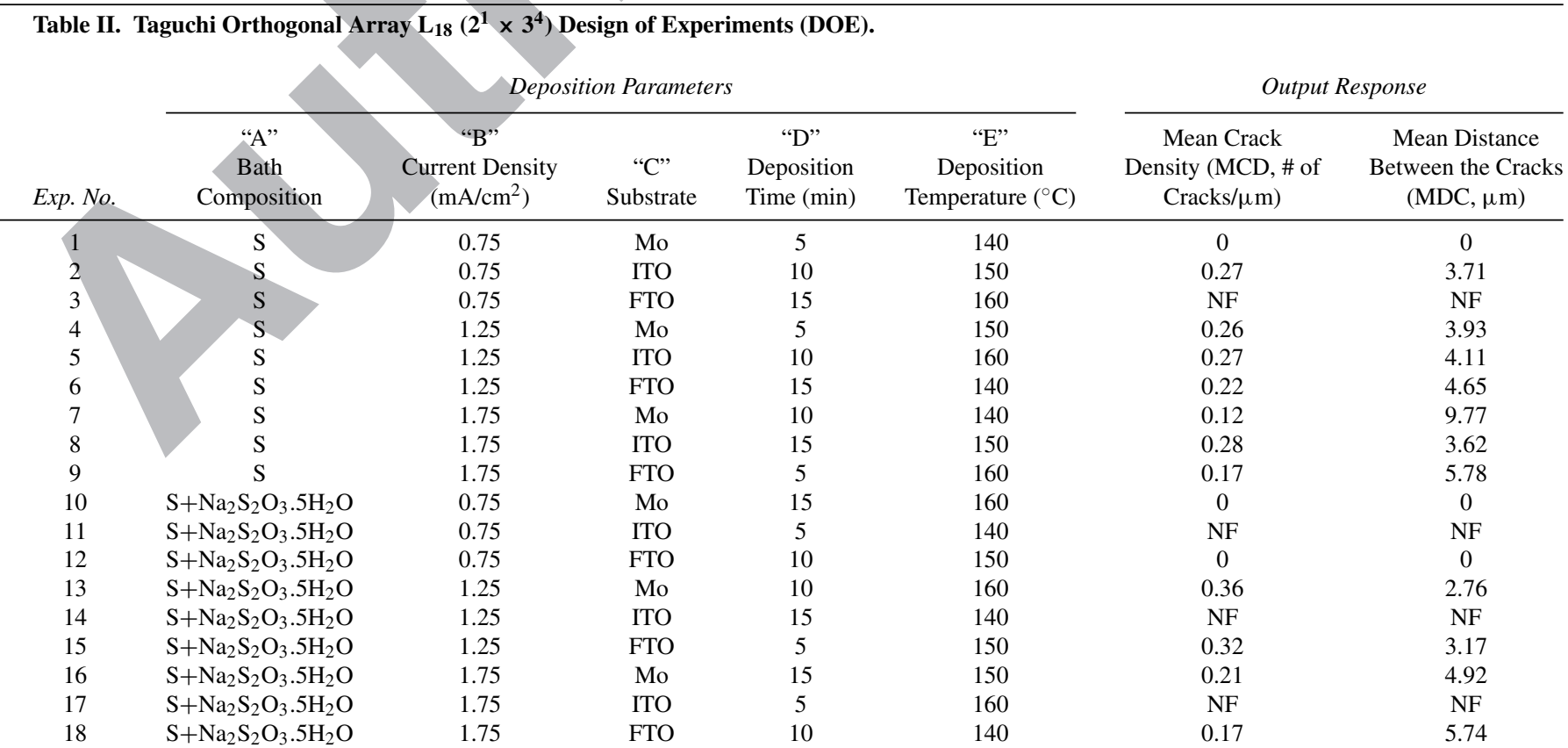




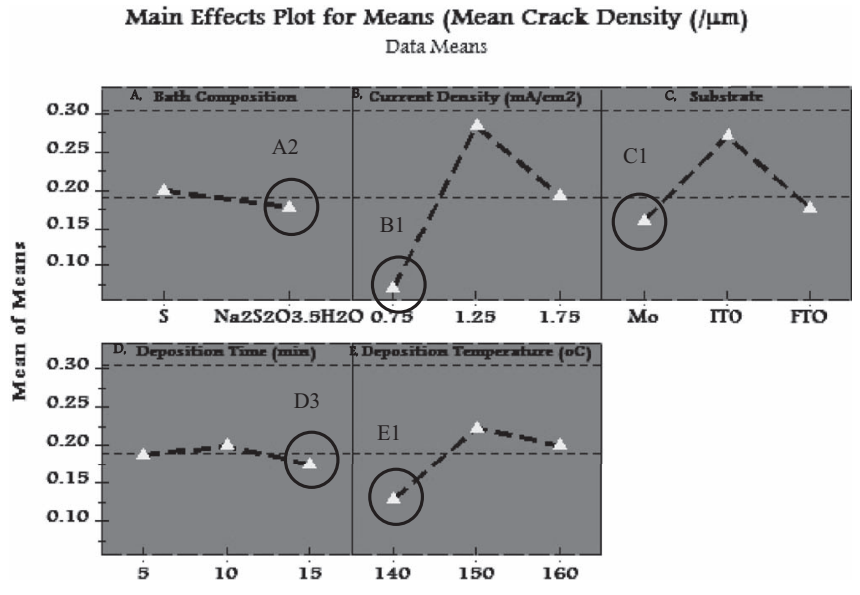

Figure 2. Optimal electrodeposition parameters (A2, B1, C1, D3, E1) from Taguchi Analysis: Main effects plot for means (mean crack density MCD (\# of cracks/ $\mu \mathrm{m})$ ).

The main effects plot for means (mean crack density) revealed 140 the optimal values for each electrodeposition parameter, as shown 141 in Figure 2. The points (triangle shape) in the plot are the mean 142 of the output response (crack density) at different levels for each 143 parameter, with a reference line (horizontal dashed line) drawn at 144 the grand mean of the output response. The lowest average mean 145 of mean crack density defines the optimal level (encircled) for that 146 deposition parameter. Therefore, according to the main effects plot 147 for means, the optimal electrodeposition parameters were A2, B1, C1, $148 \mathrm{D} 3$, and E1. It was also evident from the output response table that 149 current density was the most, while bath composition was the least, 150 significant deposition parameter, to the morphology of $\operatorname{In}_{2} \mathrm{~S}_{3}$ films, 151 as shown in Table III. The substrate and deposition temperature were 152 the second- and third- most significant deposition parameters relative 153 to cracks in $\mathrm{In}_{2} \mathrm{~S}_{3}$ films. We also believe that when a thin film was 154 electrodeposited on a thick substrate at an elevated temperature, and 155 subsequently cooled at ambient temperature, the difference between 156 the thermal expansion coefficients of the substrate and $\operatorname{In}_{2} \mathrm{~S}_{3}$ film 157 created stress and strain, further contributing to cracks in the films.

Digital imaging analysis. - In the past, our electrodeposited $\operatorname{In}_{2} \mathrm{~S}_{3}$ 159 films have shown good stoichiometries but poor morphologies. ${ }^{18,19}$ 160 Films were usually non-uniform and thicker around the edges, and 161 sometimes flaked away into the solution when pulled from the elec162 trochemical cell. The films have shown cracks, which formed porous 163 zones on the substrate. ${ }^{25,28}$ These regions of low quality could poten164 tially result in the loss of charged carriers and insufficient electrical 65 transport within the PV cells. ${ }^{29}$

To study the crack behavior as a function of deposition parameters, digital imaging analysis of SEM images was performed using fracture and buckling analysis software. ${ }^{30}$ This analytical program was written 9 using MATLAB Version 7.1 (R14), which helped us to determine the crack and buckle density at the micro/nano-scale in a reasonable

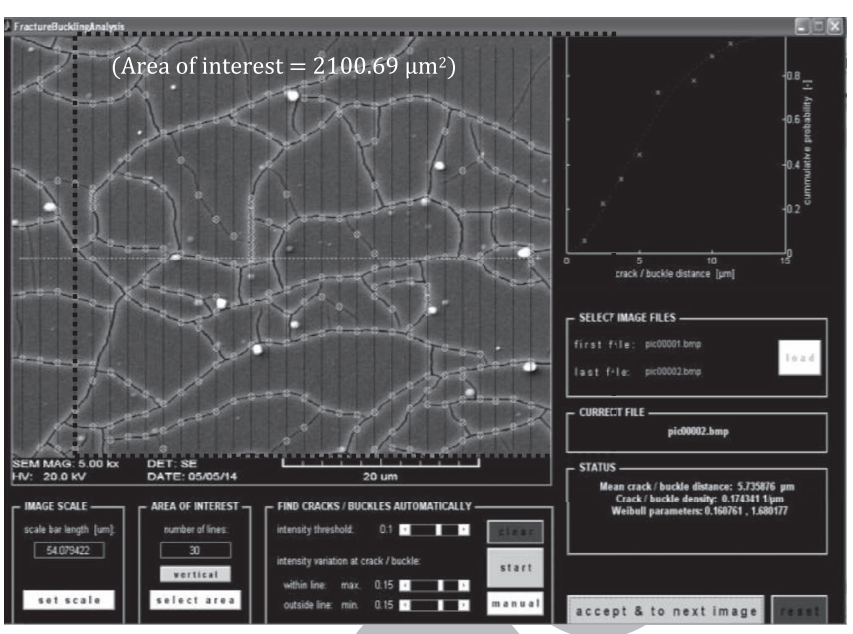

Figure 3. Digital imaging analysis: Fracture and buckling analysis software for crack density calculation. (Experiment 7, Sample 1).

amount of time with high accuracy. It investigates and detects the dark 171 features of the SEM image (as shown in Figure 3 in small circles) 172 compared to the average intensity of the image in a few minutes time. 173 The crack density is determined by linear analysis. A vertical line 174 (in parallel) pattern over the selected area of interest is superimposed $\quad 175$ onto the image, where this line pattern is perpendicular to cracks. The 176 intersections between the analysis lines and cracks are determined. 177 Hence, the crack density is determined by dividing the number of 178 intersections with the cumulative line length. ${ }^{30}$ The dotted square box $\quad 179$ indicates the area of interest, which is approximately $2100.69 \mu \mathrm{m}^{2} \quad{ }_{180}$ $(54.62 \mu \mathrm{m} \times 38.46 \mu \mathrm{m})$

SEM images (captured at magnification scale, $5 \mathrm{kX}$, distance between electron gun and sample (z-value), $11 \mathrm{~mm}$, and accelerating voltage, $20 \mathrm{kV}$ ) were taken for all $\mathrm{In}_{2} \mathrm{~S}_{3}$ films to calculate mean crack density (\# of cracks/ $\mu \mathrm{m}$ ) and mean distance between the cracks $(\mu \mathrm{m})$ as shown in Table II. The mean crack density for films deposited at a current density of $0.75 \mathrm{~mA} / \mathrm{cm}^{2}$ was 0.0685 cracks $/ \mu \mathrm{m}$, whereas, the mean crack densities for films deposited at $1.25 \mathrm{~mA} / \mathrm{cm}^{2}$ and $1.75 \mathrm{~mA} / \mathrm{cm}^{2}$ were $0.2846 \mathrm{cracks} / \mu \mathrm{m}$ and $0.2055 \mathrm{cracks} / \mu \mathrm{m}$, respectively. However, the crack densities for films deposited at current densities of $1.25 \mathrm{~mA} / \mathrm{cm}^{2}$ and $1.75 \mathrm{~mA} / \mathrm{cm}^{2}$ were unknown for four $\mathrm{In}_{2} \mathrm{~S}_{3}$ films due to poor coverage over the substrate. These films were assumed to have high crack densities since they flaked away from the substrate while rinsing with distilled water after electrodeposition.

Similarly, the mean distance between the cracks was higher for 195 films deposited at a current density of $0.75 \mathrm{~mA} / \mathrm{cm}^{2}$, compared to the 196 mean distances between the cracks for films deposited, respectively, 197 at $1.25 \mathrm{~mA} / \mathrm{cm}^{2}$ and $1.75 \mathrm{~mA} / \mathrm{cm}^{2}$. This phenomenon corresponds 198 to increased crack density that is associated with decrease in mean 199 distance between the cracks, which is also evident from Figure 4. 200 For example, the film in Experiment 7, with the lowest crack density 201 among all the $\operatorname{In}_{2} S_{3}$ films with cracks, exhibited the greatest mean 202 distance between the cracks. Similarly, the films in Experiments 9 and 203

Table III. Output Response Table for Means (Mean Crack Density).

Deposition Parameters

\begin{tabular}{cccccc}
\cline { 2 - 5 } Levels & $\begin{array}{c}\text { "A" } \\
\text { Bath } \\
\text { Composition }\end{array}$ & $\begin{array}{c}\text { "B" } \\
\text { Current Density } \\
\left(\mathrm{mA} / \mathrm{cm}^{2}\right)\end{array}$ & $\begin{array}{c}\text { "C" } \\
\text { Substrate }\end{array}$ & $\begin{array}{c}\text { "D" } \\
\text { Deposition } \\
\text { Time (min) }\end{array}$ \\
\hline 1 & 0.1989 & 0.0684 & 0.16 & 0.1880 \\
2 & 0.1772 & 0.2847 & 0.2721 & 0.2002 & 0.1284 \\
Temperature $\left({ }^{\circ} \mathrm{C}\right)$
\end{tabular}




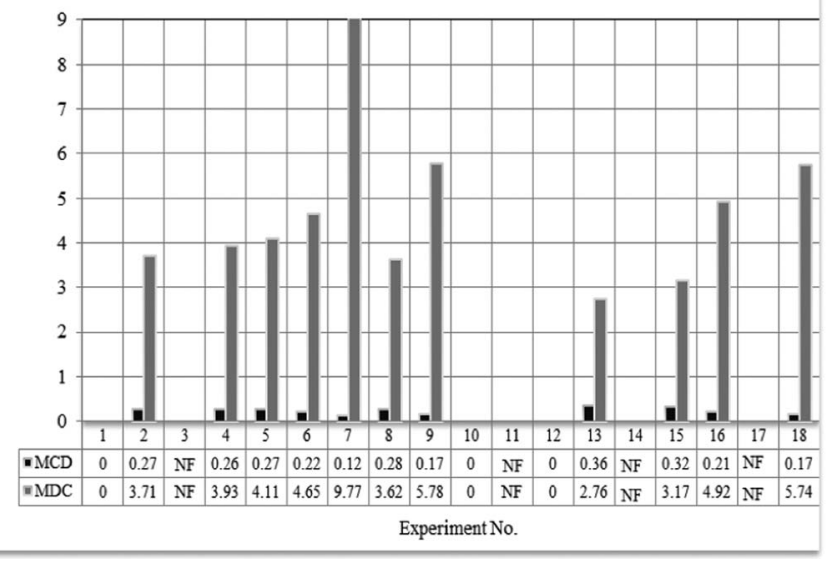

Figure 4. MATLAB simulation results (for all 18 experiments): Calculated mean crack density $(\mathrm{MCD}$, \# of cracks $/ \mu \mathrm{m})$ and mean distance between the cracks (MDC, $\mu \mathrm{m}$ ) using fracture and buckling analysis software. NF: No film.

18 had greater mean distances between the cracks due to lower crack densities.

Morphological analysis.- The cracked morphology of elec207 trochemically deposited $\operatorname{In}_{2} \mathrm{~S}_{3}$ thin films has been reported 208 previously; $;^{3,31,32}$ however, the reason for this is still not fully 209 known. The potential causes include thickness, poor incorporation 210 of solutes with solvents, ${ }^{33}$ deposition voltage, ${ }^{34}$ substrates, surface 211 contamination, ${ }^{35}$ piezoelectric effect, current density, mass transfer, ${ }^{36}$ 212 and electrolytes. ${ }^{37}$

213 In our study, we found that the current density and substrate type, 214 respectively, were the most and second-most significant deposition 215 parameters associated with the cracking behavior. Films on FTO- and 216 ITO-coated glass substrates were non-uniform, and part of the films 217 flaked away when rinsed with distilled water, whereas the films de218 posited onto Mo-coated glass substrates exhibited good uniformity 219 and adherence. However, $\operatorname{In}_{2} \mathrm{~S}_{3}$ films on all three substrates featured 220 cracks and porous zones, as were evident from SEM micrographs 221 shown in Figure 5. Current densities were found to have a significant 22 impact upon the morphology. The porosity of the films increased with 223 higher current density $\left(>1 \mathrm{~mA} / \mathrm{cm}^{2}\right)$ due to a larger rate of material 24 growth at the cathode. Moreover, the morphology of the films on ITO glass substrates was also influenced by the substrate itself and the bath composition. $\mathrm{In}_{2} \mathrm{~S}_{3}$ films deposited using $\mathrm{Na}_{2} \mathrm{~S}_{2} \mathrm{O}_{3} .5 \mathrm{H}_{2} \mathrm{O}$ as an additional sulfur source exhibited poor adhesion. Films flaked-off of the substrate after post-deposition rinsing. However, films deposited using only elemental sulfur showed good adherence, but large crack density. On the other hand, film morphology on FTO glass substrates was far better than on ITO glass substrates in terms of uniformity 2 (coverage), appearance, and adherence. Current density was the only significant factor affecting the morphology of the films. Meanwhile, molybdenum-on-glass substrates yielded the best-electrodeposited $35 \mathrm{In}_{2} \mathrm{~S}_{3}$ films. The films showed nice uniformity and adherence regard236 less of the bath composition and deposition temperature. However, 37 deposition time had a significant impact upon the cracking behavior 38 of the films. Longer deposition times (10 and $15 \mathrm{~min}$.) caused films 239 to crack due to greater thicknesses, suggesting thickness as another 240 potential cause for the cracks. Therefore, films were electroplated for 241 only 5 minutes to deposit very thin $\operatorname{In}_{2} \mathrm{~S}_{3}$ films and eliminate cracks. 242 High current density $\left(1.25 \mathrm{~mA} / \mathrm{cm}^{2}\right.$ and $\left.1.75 \mathrm{~mA} / \mathrm{cm}^{2}\right)$ yielded films 243 with high crack densities, whereas, low current density $\left(0.75 \mathrm{~mA} / \mathrm{cm}^{2}\right)$ 244 yielded almost crack-free films.

245 Compositional analysis. - In our previous work, ${ }^{25}$ we stated that 246 deposition voltage has the most significant impact upon the stoichiom247 etry of $\operatorname{In}_{2} \mathrm{~S}_{3}$ films. Therefore, in this follow-up study, we found, as 248 expected, that the current density (a strong function of deposition volt-

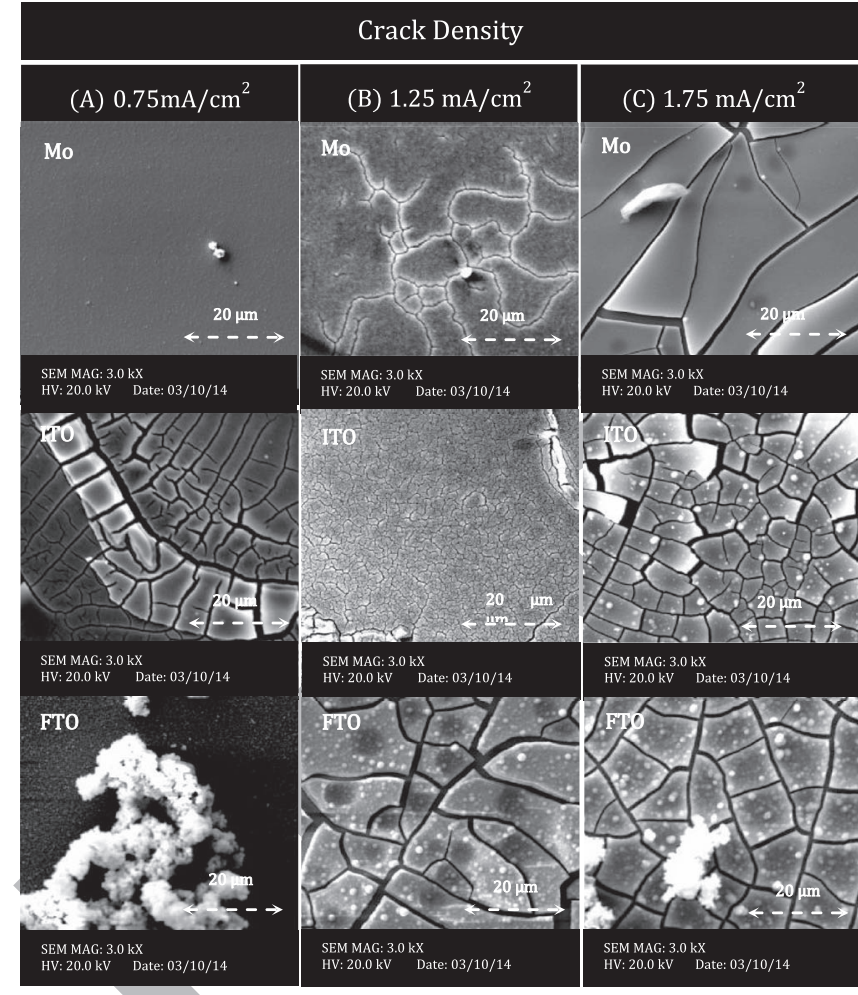

Figure 5. Electrodeposited $\operatorname{In}_{2} \mathrm{~S}_{3}$ film morphology on molybdenum (Mo)-, indium tin oxide (ITO)-, and fluorine-doped tin oxide (FTO)-coated glass substrates at three different current densities: (A) $0.75 \mathrm{~mA} / \mathrm{cm}^{2}$, (B) 1.25 $\mathrm{mA} / \mathrm{cm}^{2}$, and (C) $1.75 \mathrm{~mA} / \mathrm{cm}^{2}$.

age) has a significant impact upon the composition of the films. Films 249 deposited at low current density produced crack-free films; however, 250 the composition was slightly sulfur-rich as-deposited (see Table IV). 251 Subsequently, $\operatorname{In}_{2} \mathrm{~S}_{3}$ films were annealed at different annealing tem- 252 peratures $\left(200^{\circ} \mathrm{C}, 300^{\circ} \mathrm{C}\right.$, and $\left.400^{\circ} \mathrm{C}\right)$ for an hour in air to study the ${ }_{253}$ effect of annealing and improve the stoichiometry. After annealing, 254 films annealed at $300^{\circ} \mathrm{C}$ for an hour in air exhibited nearly ideal sto- 255 ichiometric ratios between sulfur and indium (S/In: 3/2). However, 256 the films contained a higher percentage of oxygen due to oxygen 257 substituting with sulfur to form $\operatorname{In}_{2} \mathrm{~S}_{3-\mathrm{x}} \mathrm{O}_{\mathrm{x}}$ during the process.

\section{Summary of Work}

Morphological and compositional properties of electrodeposited 260 $\mathrm{In}_{2} \mathrm{~S}_{3}$ films were studied by varying deposition parameters. Digital 261 imaging analysis of SEM images using fracture and buckling analysis 262 software was performed to quantify the cracks in films. The crack den- 263 sity and mean distance between the cracks were calculated and studied 264

Table IV. EDS Data for $\operatorname{In}_{2} S_{3}$ Films Electrodeposited at 0.75 $\mathbf{m A} / \mathrm{cm}^{2}$.

\begin{tabular}{lcccc} 
& $\begin{array}{c}\text { As- } \\
\text { deposited }\end{array}$ & $\begin{array}{c}\text { Annealed } \\
200^{\circ} \mathrm{C}\end{array}$ & $\begin{array}{c}\text { Annealed } \\
300^{\circ} \mathrm{C}\end{array}$ & $\begin{array}{c}\text { Annealed } \\
400^{\circ} \mathrm{C}\end{array}$ \\
\cline { 2 - 5 } Element & \multicolumn{4}{c}{ Atomic\% } \\
\hline Carbon (C) & 24.3 & 8.93 & 0 & 19.36 \\
Oxygen (O) & 19.99 & 32.34 & 17.85 & 58.17 \\
Aluminum (Al) & 0 & 0 & 0 & 0.19 \\
Sulfur (S) & 32.33 & 34.05 & 49.21 & 11.21 \\
Indium (In) & 23.38 & 24.68 & 32.94 & 11.08 \\
(S+O)/In Ratio & 2.23 & 2.69 & 2.03 & 6.26 \\
S/In Ratio & 1.38 & 1.37 & 1.49 & 1.01
\end{tabular}


265 as a function of deposition parameters. Using the Taguchi Method,

266 we succeeded in optimizing the electrodeposition parameters and un267 derstanding their influence upon the properties of the films, which are 268 important for optimizing the device efficiency. The optimized param269 eters helped us to improve the morphology and achieve crack-free 270 films with near-to-ideal stoichiometry. Current density was the most 271 significant deposition parameter correlated with cracks in the films, 272 and the compositions of the films were highly dependent upon it. The 273 composition of the bath was the least significant deposition parameter 274 relative to effect upon the morphology and composition. 276 glass substrates using ethylene glycol-based electrolytes, to study their 277 growth behavior and surface morphology. The optimized deposition 278 parameters were sulfur plus sodium thiosulfate-containing electrolytic 279 solutions (A2), $0.75 \mathrm{~mA} / \mathrm{cm}^{2}$ current density (B1), molybdenum280 coated glass substrates (C1), 15 minute deposition time (D3), and $281140^{\circ} \mathrm{C}$ deposition temperature (E1) (as shown in Figure 2). Using 282 optimized deposition parameters, we were able to successfully syn283 thesize $\operatorname{In}_{2} \mathrm{~S}_{3}$ films with planar surface morphologies and nearly ideal 284 stoichiometric ratios. The films were thin, uniform, adherent, ho285 mogenous, and crack-free. In order to reduce the thickness of the 286 films and further avoid cracks, the films were electroplated for only 2875 minutes.

Taguchi analysis proved that the current density had the most 289 significant impact upon the morphology and composition of $\operatorname{In}_{2} \mathrm{~S}_{3}$ 290 films. Films synthesized at higher current densities $\left(1.25 \mathrm{~mA} / \mathrm{cm}^{2}\right.$ and $2911.75 \mathrm{~mA} / \mathrm{cm}^{2}$ ) exhibited high crack densities, whereas, at lower cur292 rent density $\left(0.75 \mathrm{~mA} / \mathrm{cm}^{2}\right)$, films exhibited minimal or no cracks. 293 The porosity of the films increased with higher current density due 294 to the larger rate of material growth at the cathode. The mean crack 295 density increased approximately by 400 to 600 times for the films 296 electroplated at higher current densities on all three substrates. The 297 substrate and deposition temperature were the second- and third-most 298 significant deposition parameters correlated with cracks in films. The 299 interaction between the two was also significant, suggesting that the 300 mismatch between the thermal expansion coefficients of the substrate 301 and $\operatorname{In}_{2} \mathrm{~S}_{3}$ film created stress and caused the films to crack. Further302 more, films deposited onto FTO-glass substrates also exhibited nice 303 morphologies at low current density, while films on ITO-glass sub304 strates showed poor uniformity and adherence at all levels. Films 305 exhibited different morphologies on different substrate types, even 306 with the same deposition parameters. The microstructures in films 307 differed from each other in terms of size, orientation, and appearance 308 although they featured cracks, as shown in Figure 5. Similarly, the 309 composition of the films was highly influenced by the current density. 310 Films electrodeposited at low current density yielded slightly sulfur311 rich films, which were then annealed for an hour at $300^{\circ} \mathrm{C}$. During the 312 annealing treatment, excess sulfur was removed and the stoichiometry 313 between sulfur and indium was nearly ideal (S/In : 3/2).

\section{Acknowledgments}

The authors acknowledge the gracious support provided by 316 Arkansas State University, National Science Foundation grant EPS3171003970 administered by the Arkansas Science and Technology 318 Authority, and NASA grant NNX09AW22A administered by the 319 Arkansas Space grant Consortium. Dr. Alan Mantooth, Kathy Kirk, 320 Dr. Greg Salamo, Dr. Omar Manasreh, Dr. Alex Biris, Dr. Tansel 321 Karabacak, Dr. Hyewon Seo, and other collaborators at the University 322 of Arkansas (Fayetteville, Little Rock, and Pine Bluff campuses) are 323 also thanked, as are Dr. Keith Hudson and Laura Holland at ASGC, 324 and Dr. Gail McClure at ASTA. The authors are also grateful for the 325 ongoing support provided by Arkansas State University, particularly
Dr. Paul Mixon, Dr. William Burns, Dr. Tom Risch, Dr. Tanja McKay, ${ }_{326}$ Dr. John Pratte, and Dr. Andrew Sustich.

Thanks also go to Dr. Richard Segall and Dr. Ilwoo Seok for an introduction to the Taguchi Method, and to Dr. Stan Trauth for the use of the SEM/EDS unit.

\section{References}

1. A. Dutta, S. K. Panda, S. Gorai, D. Ganguli, and S. Chaudhuri, Mater. Res. Bull., 43, 983 (2008).

2. J. Bartolomé, D. Maestre, A. Cremades, and J. Piqueras, Microsc. Microanal., 18, 121 (2012).

3. A. M. Abdel Haleem, M. Sugiyama, and M. Ichimura, Mater. Sci. Appl., 3, 802 (2012).

4. T. T. John, S. Bini, Y. Kashiwaba, T. Abe, Y. Yasuhiro, C. Kartha, and K. Vijaykumar, Semicond. Sci. Technol., 6, 491 (2003).

5. N. A. Allsop, A. Schönmann, H. J. Muffler, M. Bär, M. C. Lux-Steiner, and Ch-H. Fischer, Prog. Photovoltaics, 13, 607 (2005).

6. M. I. Hossain, P. Chelvanathan, M. Zaman, M. R. Karim, M. A. Alghoul, and N. Amin, Chalcogenide Lett., 8.5315 (2011).

7. K. Yamaguchi, T. Yoshida, and H. Minoura, Thin Solid Films, 431/432, 354 (2003).

8. Y. Hsiao, C. Lu, L. Ji, T. Meen, Y. Chen, and H. Chi, Nanoscale Res. Lett., 9, 32 (2014).

9. M. Cansizoglu, R. Engelken, H. Seo, and T. Karabacak, ACS Nano, 4, 733 (2010).

10. B. Chai, P. Zeng, X. Zhang, J. Mao, L. Zan, and T. Peng, Nanoscale, 4, 2372 (2012)

11. X. Sheng, L. Wang, G. Chen, and D. Yang, J. Nanomater, 2011, 5 (2011)

12. N. Naghavi, S. Spiering, M. Powalla, B. Cavana, and D. Lincot, Prog. Photovoltaics, 11, 437 (2003).

13. P. Jackson, D. Hariskos, R. Wuerz, W. Wischmann, and M. Powalla, Phys. Status Solidi RRL, 8, 219 (2014)

14. R. K. Pandey, S. N. Sahu, and S. Chandra, Handbook of semiconductor electrodeposition, p. 37, New York: Taylor \& Francis (2010).

15. D. Lincot, Thin Solid Films, 487, 40 (2005).

16. N. Naghavi, E. Chassaing, S. Galanti, G. Renou, M. Soro, M. Bouttemy, A. Etcheberry, and D. Lincot, J. Electrochem. Soc., 10, 155 (2011)

17. J. S. Wellings, A. P. Samantilleke, S. N. Heavens, P. Warren, and I. M. Dharmadasa, Sol. Energy Mater. Sol. Cells, 93, 1518 (2009).

18. M. J. Newell, M. A. Mughal, R. Engelken, F. Felizco, J. Hall, J. Vangilder, D. McNew, S. Thapa, and Z. Hill, in: Proceedings of the 37th IEEE Photovoltaic Specialis Conference, Seattle, WA (2014), p. 1638. Available http://ieeexplore.ieee.org/xpl/ 6186202.

19. M. A. Mughal, M. J. Newell, R. Engelken, F. Felizco, J. Hall, J. Vangilder, D. McNew, S. Thapa, and Z. Hill, in: Proceedings of the 37th IEEE Photovoltaic Specialist Conference, Denver, CO (2014), C27:473. Available http://www.ieeepvsc.org/ePVSC/ core routines/view abstract no php?show close window=yes\&abstractno $=2044$.

20. A. C. Castillo, R. C. Ambrosio Lazaro, E. M. Lira Ojeda, C. A . Martinez Perez, M. A. Quevedo-Lopez, and F. S. Aguirre Tostado, Chalcogenide Lett., 10, 421 (2013).

21. P. Dale and L. Peter, Adv. Electrochem. Sci. Eng., 12, 1 (2010).

22. D. A. Mazón-Montijo, M. T. S. Nair, and P. K. Nair, ECS J. Solid State Sci. Technol. 2, 465 (2013)

23. S. Lugo-Loredo, Y. Peña-Méndez, M. Calixto-Rodriguez, S. Messina-Fernández, A. Alvarez-Gallegos, A. Vázquez-Dimas, and T. Hernández-García, Thin Solid Films, 550, 110 (2013)

24. R. Kumaresan, M. Ichimura, N. Sato, and P. Ramasamy, Mater. Sci. Eng., 96, 37 (2002)

25. M. A. Mughal, M. J. Newell, R. Engelken, J. Vangilder, S. Thapa, K. Wood B. R. Carroll, and J. B. Johnson, J. Nanomater, 2014, 1 (2014).

26. E. Agastra, P. Giuseppe, S. Stefano, and T. Ruggero, Int. J. RF Microw. Computer Aided Eng., 23, 357 (2013).

27. D. M. Steinberg and D. Burnsztyn, Stat. Sin., 8, 67 (1998).

28. M. A. Mughal, M. J. Newell, R. Engelken, J. Vangilder, S. Thapa, J. Hall, D. McNew, F. Felizco, K. Wood, B. R. Carroll, and J. B. Johnson, in: Technical Proceedings of the 2013 NSTI Nanotechnology Conference, Washington, DC (2013) p. 523. Available http://www.nsti.org/procs/Nanotech2013v3/6/M6.158.

29. M. Lajnef and H. Ezzaaouia, The Open Appl. Phys. J., 2, 23 (2009).

30. S. Frank and R. Spolenak, Laboratory for Nanometallurgy, ETH Zurich, Switzerland (2008) [Online] Available http://www.mathworks.com/matlabcentral/fileexchange/ 20475-determination-of-crack-and-buckle-density-by-digital-image-analysis

31. A. M. Abdel Haleem and M. Ichimura, Thin Solid Films, 516, 7783 (2008).

32. R. S. Mane and C.D. Lokhande, Mater. Chem. Phys., 78, 15 (2002).

33. G. F. Fulop and R. M. Taylor, Annu. Rev. Mater. Sci., 15, 197 (1985).

34. A. S. Baranski, W. R. Fawcett, and C. M. Gilbert, J. Electrochem. Soc., 154, D669 (1983).

35. M. N. Mammadov, A. Sh. Aliyev, and M. Elrouby, Int. J. Thin Films Sci. Tech., 2, $43(2012)$.

36. V. S. Saji, S-M. Lee, and C. W. Lee, J. Korean Electrochem. Soc., 14, 61 (2011)

37. S. J. Abbas, Basrah J. Sci., 25, 1 (2007). 332 335 ${ }_{336} \mathrm{Q}$ 338 339 340 341 342 343 345
346 347 350 351 352 353 355 356 357 358 359 362 363 365 366 368 369 370 371 372 373 375 376 378
379 380 382 386 387 389 390 391 392 393 394 395 396 397 398
399 


\section{Query}

Q1: AU: Please provide a digital object identifier (doi) for $\operatorname{Ref}(\mathrm{s}) 3,6,11,16,20,21,27,34,35$, and 37. For additional information on doi's please select this link: http://www.doi.org/. If a doi is not available, no other information is needed from you. 